IJ§ER

ISSN: $2149-5939$
International Journal of Social Sciences and Education Research

Online, http://dergipark.gov.tr/ijsser

Volume: 2(2), 2016

\title{
Barriers to innovation in Morocco: The Case of Tangier \& Tetouan Region
}

\author{
Hicham Achelhi ${ }^{1} \quad$ Narjisse Lagziri ${ }^{2} \quad$ Mustapha Bennouna $^{3} \quad$ Patrick Truchot $^{4}$
}

Received Date: $19 / 11 / 2015$

Accepted Date: 12 / $02 / 2016$

\begin{abstract}
Innovations are the result of a joint effort of a number of parties involved in the process of improving a country. Innovation has increasingly been recognised to be the key growth of Morocco and has attracted significant levels of academic attention over recent years. Nevertheless, there has however been less focus on the factors which prevent or inhibit innovative activity, the "barriers approach to innovation" especially in developing countries. In the Arab regions, studies on barriers to innovation are sparingly rare. There has not been research in the relevant literature that has identified the innovation barriers in Morocco; a detailed review related to innovation barriers has been conducted. This paper reports on the results of a study that examined barriers to firms' innovation on a sample of 76 managers of enterprises in the Tangier\&Tetouan region. Tangier\&Tetouan is a dynamic region, and is also the recipient of generous investment, and is considered a strategic area for the development of Morocco. Indeed, the region is an important industrial center at the national level, occupying second place with 10\% domestic value added, almost $8 \%$ of production and $14 \%$ of exports. The aim of this study is to determine the barriers in the innovation process in the Tangier\&Tetouan region, and investigate the interrelations among them and develop a model that may measure the interacting effects of the barriers.
\end{abstract}

The approach is based on a review of the scientific papers; analysis of available statistical data, national development documents, empirical researches and other secondary data. An in-depth study of fifteen barriers to innovation was completed through distributing questionnaires. The results were initially summarized using statistics to provide a better understanding of the respondents and characteristics of the responding companies. The paper concludes with an analysis of the complementarities between obstacles to arrive at the primary factors that are obstacles to innovation activity. Both internal and external determinants play a significant role in hindering innovation development. The analysis also explores the differences between firms by industry type and firm size. Furthermore, the level of importance of obstacles is different for innovator and non-innovator firms. Among the main results set for this research it cannot generalize the model of innovation in the region of Tangier\&Tetouan.

This paper is should be taken as the first study not only in investigating the barriers in the innovation process in Tangier\&Tetouan region, but also in developing a model that may be used in solving the innovation barriers. The results of the study may be useful for both government and enterprises. The research results can be used in the development of public policy aimed at supporting and encouraging innovation among enterprises in Tangier\&Tetouan region.

Keywords: Innovation Barriers, Interrelation, Model, Tangier\&Tetouan region.

\section{Introduction}

In recent years, innovation has become the heart of business concerns of a country and the current economic difficulties do not in any way hinder this phenomenon. It is necessary to continue to innovate in times of crisis to differentiate. However, a question arises for developing countries: Can we really anticipate these countries to expand their economy as fast as developed countries, while they have not ceased to benefit from benefits of technological innovation over

\footnotetext{
${ }^{1}$ Abdelmalek Essaadi Un., Faculty of Science \& Technology, Morocco, achelhihicham@yahoo.fr

${ }^{2}$ Abdelmalek Essaadi Un., Tangier, BP : 416, Morocco, lagziri narjisse@yahoo.fr

${ }^{3}$ Abdelmalek Essaadi Un., Tangier, BP : 416, Morocco, bennouna.mustapha@gmail.com

${ }^{4}$ INPL-National School of Ind. Systems Engineering, France. patrick.truchot@ensgsi.inpl-nancy.fr
} 
Achelhi, H., Lagziri, N., Bennouna, M., Truchot, P. (2016). Barriers to innovation in Morocco: The Case of Tangier \& Tetouan Region. International Journal of Social Sciences and Education Research, 2 (2), $592-$ 612.

the centuries? It is certain; in any case, they will overcome this. There are a number of pitfalls among the barriers of innovation. Today, innovation is widely recognized as an essential lever for the development and growth of businesses and nations.

In fact, few years in the past, we saw transfer of manufacturing from the West to countries with low labor costs due to globalization and the phenomenon continues to grow. International companies can now make their own choices within a wide range of possibilities, depending on the case, they first choose a country or a large area and then select a "short list" of locations of interest, or in some specialized areas where only a few major international cities have interesting features, they are established by specialists in firms the direct lists of possible sites. In this sense, the recent literature provides a strong territorial innovation.

In the economic region, it reached a sufficient size that appears more appropriate geographically successful, some authors do not hesitate to consider that big states are no longer adapted to the world today and boast the effectiveness of region-state (Ohmae, 1995). The region is becoming increasingly important in innovation policies (Madiès T and JC Prager, 2008).

In Morocco, six of the sixteen regions contribute alone to $63.8 \%$ of gross domestic product (GDP). Despite these large differences in productivity regions in Morocco innovation policies are still domestic. Today, we are witnessing a real debate on the effectiveness of the national innovation policy in Morocco. Is it adapted to the specific characteristics of each region?

However, to develop a regional innovation policy, we are led to ask ourselves several points concerning the state of innovation in the region. Innovations are the result of a joint effort of a number of parties involved in the process. Thus, the present work aims to study the barriers to innovation in one of the most attractive regions of Morocco, a region known for its unique location, its economic strengths and its industrial position "2nd industrial hub in Morocco", the Tangier-Tetouan region.

\section{Literature review}

Studies on innovation have identified in detail the sources and drivers of innovation, paying particular attention to technological and organizational capabilities that companies need to develop to become innovators (eg Schumpeter, 1950, Dosi 1988, Nelson and Winter, 2002; Von Hippel, 1994). However, this literature has been relatively less systematic in examining the factors that block innovation, especially in developing countries. The barriers approach to innovation is much more recent than that that addresses the determinants of innovation (Galia and al., 2004, Segarra-Blasco and al. 2008). It identifies barriers to innovation and to know their nature, importance and impact of the whole process. Its objective is to measure the effects and consequences, which is not easy (Hadjimonalis, 1999). This approach allows assessment of the effectiveness of public actions and determine corrective actions to overcome or eliminate these barriers. In terms of impact on the innovation process, a barrier has quite the potential to prevent innovation, reduce or increase the innovative activities of the difficulties, costs and timing of the process. Piater (1984) has stated that a barrier to innovation is any factor that influences negatively the innovation process. Companies that are not able to overcome initial barriers cannot start innovation while growing companies may be forced to abandon innovative projects. While companies who obtain status, innovator can expect to encounter obstacles throughout this process, as they move away from the starting line. 
Achelhi, H., Lagziri, N., Bennouna, M., Truchot, P. (2016). Barriers to innovation in Morocco: The Case of Tangier \& Tetouan Region. International Journal of Social Sciences and Education Research, 2 (2), 592612 .

Barriers to innovation can be classified in different ways and different typologies e.g. origin, source. The size, sector and industry affiliation of the company also have a role in the types of obstacles faced by companies. In this meaning, Hadjimanolis (2003) reported that the size has an important impact on the innovation barriers. In small businesses, the barriers to innovation are generally perceived as more serious, while large companies generally face internal barriers such as organizational rigidities (Dougherty, 1992), and the lack of incentives to innovate (Henderson, 1993).

The activity sector in the firms, Tourigny and Le (2003) provide empirical evidence that firms in low and medium technology generally face less obstacles than those in high-tech industries because of the greater intensity of innovation in the second. Moreover, since the laws and regulations may also be sector-specific, we're likely to see these forms of external barriers differ across sectors. Barriers may vary also by sector (Preiss1, 1998). The literature review has shown the existence of a relationship also between the barriers of innovation and appurtenance of the company (domestic or foreign). The multinational firms prefer research activities in rewind (Gobe, 2001) by horizontal investments (trade, real estate, etc.) with a low investment in the spinneret firms. This strategy leads to a low accumulation of the technological and managerial know-how, in a low level of long-term investment (a manifestation of strong risk aversion), and in a low qualification effort and recruitment of trained manpower (Ould Aoudia, 2006). Local subsidiaries are considered branches that are able to exploit the key asset, but unable to develop assets that could be transferred back and operated within the global activities of the parent company.

A useful classification of barriers is made by Piatier (1984); he classifies the company's internal and external barriers.

\section{i. External Barriers}

Bureaucratic procedures, lack of properly settled national strategy, problems in policy communication and execution, may cause abnormal external barriers for innovation processes. Piater (1984) admits that lack of government assistance was the third most important barrier to innovation in European countries.

External barriers arise when the company or innovator has difficulty accessing the offer (obtaining information technology, raw materials, and finance), demand (consumer needs, their perception of risk innovation, limits of domestic and foreign markets) and the environment (government regulations, political action). These barriers are clearly more important than internal, perhaps because most domestic issues can be resolved by company that is committed to the innovation activity (Lim and Shyamala, 2007).

\section{ii. Internal Barriers}

Internal barriers are related to resources (lack of substantive, technical expertise, time management, culture ...) and human nature (the attitude of top management and employee resistance to risk ...). They thus correspond to all the internal resources of the company: financial and human. To these may be added the factors related to the structure of the company (Hadjimanolis, 1999). Its internal barriers when it lacks internal funds and staff when the company believes that the risks and costs of innovation are too high. Two very important things about human capital: capacity and motivation. Capacity may be limited by knowledge. Knowledge barriers arise due to lack of knowledge or low absorptive capacity. Internal barriers such as resistance to change, lack of time 
Achelhi, H., Lagziri, N., Bennouna, M., Truchot, P. (2016). Barriers to innovation in Morocco: The Case of Tangier \& Tetouan Region. International Journal of Social Sciences and Education Research, 2 (2), 592612.

(including time management), the contradictions in the strategic or lack of qualifications... scored significantly higher than the financial barriers.

A general analysis of the work focuses on obstacles to innovation shows a real lack of studies on developing countries.

Table 1. Summary of major international made on barriers to innovation in the country by authors

\begin{tabular}{|c|c|c|c|}
\hline & Country & Year & Authors \\
\hline 1 & USA & 1990 & Acs and Audresch \\
\hline 2 & Suede & 1998 & Yinenpaa \\
\hline 3 & Cyprus & 1999 & Hadjimamolis \\
\hline 4 & India & 2001 & Clancy \\
\hline 5 & Canada & 2002 & Mohnen\&Rosa, Badlwin\&Lin \\
\hline 6 & Europe & 2002 & Canepa and Stonea \\
\hline 7 & Spain & 2002 & March-Chorda and al \\
\hline 8 & Germany & 2004 & Fes \\
\hline 9 & France & 2004 & Galia\&Legros \\
\hline 10 & Canada & 2004 & Tourigny\&Le \\
\hline 11 & Ireland, Denmark, Germany and Italy & 2005 & Mohnen\&Roller \\
\hline 12 & Spain & 2005 & Gonzalez and al \\
\hline 13 & Italy & 2007 & Simmona Iammarino and al \\
\hline 14 & Netherlands & 2007 & Tiwari \\
\hline 15 & Malaysia & 2007 & Lim\&Shamalya \\
\hline 16 & Netherlands & 2008 & Mohnen and al \\
\hline 17 & England & 2008 & D'Este and al \\
\hline 18 & Portugal & 2008 & Silva and al \\
\hline 19 & Spain & 2009 & Madrid Guijarro and al \\
\hline 20 & Turkey & 2010 & Saataoglu \\
\hline 21 & Turkey & 2010 & Demirbas \\
\hline 22 & China & 2011 & Zhu and al \\
\hline 23 & Iran & 2011 & Kamalian and al \\
\hline 24 & Latvia & 2011 & Lukjanska \\
\hline 25 & Tunisia & 2011 & Rahmouni \\
\hline 26 & Iran & 2012 & Afrooz \\
\hline
\end{tabular}

In the Tangier\&Tetouan region, many multinational companies are based in the region for the low cost of manpower, proximity to Europe and for the infrastructure quality in the region. Their productions are designated to be sold outside the regions of Morocco. These companies do not choose Morocco for commercial reasons but for purely financial reasons. Innovation and R\&D are not part of their strategy. These companies are nominated in our research as "Foreign firms".

The Moroccan companies operating in the region, we will call them "National firms"

\section{Methodology}

To search the main obstacles to innovation in the Tangier-Tetouan region, the literature related to innovation barriers has been completely revised. Following the literature review, many barriers have been found to be effective in the process of innovation. 
Achelhi, H., Lagziri, N., Bennouna, M., Truchot, P. (2016). Barriers to innovation in Morocco: The Case of Tangier \& Tetouan Region. International Journal of Social Sciences and Education Research, 2 (2), 592612.

A working group was formed to select the list of barriers to investigate in the region of TangierTetouan. This group includes two academics who have studied innovation, two nationally recognised innovation experts and three industrial from the region. The group was invited to analyze the internal and external barriers to get a list of barriers to study in the Tangier-Tetouan region. In total, 14 barriers were identified:

1. Strategy management

2. Government policy

3. The high cost of innovation

4. Unqualified personnel

5. Culture

6. Resistance to change

7. Economic risk

8. Lack of market information

9. Lack of information on technology

10. Difficulty of finding a partner

11.Lack of access to knowledge network

12. No relationship with the university

13. Lack of a policy to protect intellectual property rights

14. Lack of results of $R \& D$.

The research was conducted in four stages:

- In the first step, the results of the survey with 76 companies are treated with conventional statistical analysis tools (classification, meaning, standard deviation and correlation coefficient).

- In the second step, we used the Delphi method to establish the relationship between the barriers of innovation in the region and eventually found the accessibility matrix.

The Delphi method is the first step of the forecasting process; integrate/combine with other methods in a comprehensive. The method can serve as a tool of acculturation (development of a common culture within an organization). The Delphi method aims to highlight convergence of opinions and generate some consensus on specific topics, often with a significant forward-looking, with the consultation of experts through a series of questionnaires (Dalkey\&Helmer, 1963). The choice of these experts must take into count of their knowledge on the subject concerned, their legitimacy from the panel of experts that they could represent their availability during the process of the Delphi survey and independence in relation to commercial pressures, political or other.

- In the third step, the elements will be analyzed by the structural analysis of MicMac and type of business model will be developed. 
Achelhi, H., Lagziri, N., Bennouna, M., Truchot, P. (2016). Barriers to innovation in Morocco: The Case of Tangier \& Tetouan Region. International Journal of Social Sciences and Education Research, 2 (2), $592-$ 612 .

The structural analysis is to clarify the "structure" of the system, or better, the structure of relations among its elements or variables. The structure of the system is important for understanding, especially since it retains certain permanence. It's best to analyze a contextual relationship to "realize" what was chosen. This means that an obstacle will create another obstacle. For analyzing the barriers in developing SSIM, the following four symbols have been used to denote the direction of relationships between barriers ( $i$ and $j$ ):

$\mathrm{V}=$ Barrier $\mathrm{i}$ will help achieve barrier $\mathrm{j}$;

$A=$ Barrier $j$ will be achieved by barrier $i$;

$\mathrm{X}=$ Barrier $\mathrm{i}$ and $\mathrm{j}$ will help achieve each other;

$\mathrm{O}=$ Barriers $\mathrm{i}$ and $\mathrm{j}$ are unrelated.

The SSIM has been converted into a binary matrix, called the reachability matrix by substituting $\mathrm{X}, \mathrm{A}, \mathrm{V}$ and $\mathrm{O}$ by 1 and 0 . The substitution of 1 and 0 are as per the following rules:

- If the (i, j) entry in the SSIM is V, the (i,j) entry in the reachability matrix becomes 1 and the $(\mathrm{j}, \mathrm{i})$ entry becomes 0 .

- If the $(i, j)$ entry in the SSIM is A, the $(i, j)$ entry in the reachability matrix becomes 0 and the $(j, i)$ entry becomes 1 .

- If the (i, j) entry in the SSIM is X, the (i,j) entry in the reachability matrix becomes 1 and the $(j, i)$ entry also becomes 1 .

- If the (i,j) entry in the SSIM is $\mathrm{O}$, the (i, j) entry in the reachability matrix becomes 0 and the $(\mathrm{j}, \mathrm{i})$ entry also becomes 0 .

The objective of MicMac analysis is to analyze the driver power and dependence power of the variables (Mandal and Deshmukh, 1994). The variables are classified into four clusters. The first cluster consists of the "autonomous barriers" that have weak driver power and weak dependence. These barriers are relatively disconnected from the system, with which they have only a few links, which may be strong. The second cluster consists of the dependent enablers that have weak driver power but strong dependence. Third cluster has the linkage barriers that have strong driving power but also strong dependence. These barriers are unstable in the fact that any action on these barriers will have an influence on the others and also a feedback on themselves. The fourth cluster includes the independent barriers having strong driving power but weak dependence. It is observed that a variable with a very strong driving power, called the key variables, falls into the category of independent or linkage barriers.

- Finally, we present one of the most important key that allow effective action against these innovation barriers.

\section{Findings of the study}

To ensure that we have the best presentation of our sample, we've selected a representative sample of the regional industry. From a list of 500 companies, we've selected those that add value in the region: 142 companies that represent different sectors and types were selected. Firstly, the questionnaire was sent to five companies in the region and to the director of the Moroccan R\&D as a pilot study to validate the questionnaire. Then, based on the responses, adjustments were 
Achelhi, H., Lagziri, N., Bennouna, M., Truchot, P. (2016). Barriers to innovation in Morocco: The Case of Tangier \& Tetouan Region. International Journal of Social Sciences and Education Research, 2 (2), 592612.

made; and the final questionnaire was sent to 142 companies. The enterprises that offered to answer our questionnaire and their data was exploitable were 76 units, which made the response rate of $53.5 \%$.

The construction of a valid measurement of barriers requires that we don't only measure whether a firm's manager encounters or doesn't encounters the obstacles, but it also needs to measure the extent of obstacles. A barrier of low importance cannot exert any negative impact on innovation, while an obstacle with a little larger importance can delay a project of innovation and products, or processes without making it impossible to achieve. In this case, we asked business managers from the region to tell us the severity degrees of the 14 barriers. This severity of barriers is related to its impact on innovation projects (delay, modification, cancellation ...) over the past four years.

The severity scale used is:

- $\quad 1=$ Obstacle didn't cause any delay

- $\quad 2$ = Obstacle slightly delayed

- $\quad 3=$ Obstacle moderately retarded

- $\quad 4$ = Obstacle which has seriously delayed

- 5 = Obstacle that made the innovation possible

4.1. The severity of barriers of innovation in the Tangier-Tetouan region by firm size

The following table shows the average severity of 14 obstacles by firm size:

Table 2 .The average severity of obstacles by firm size

\begin{tabular}{|l|c|c|c|}
\cline { 2 - 4 } \multicolumn{1}{c|}{} & \multicolumn{2}{c|}{ The average severity barriers by company size } \\
\hline Barriers & VSE & SMEs/SMIs & Large-scale enterprise \\
\hline Strategy management & 2,0 & 3,3 & 3,3 \\
\hline Government policy & 3,0 & 2,6 & 3,1 \\
\hline The high cost of innovation & 4,7 & 3,6 & 2,3 \\
\hline Unqualified personnel & 4,5 & 3,1 & 2,4 \\
\hline Culture & 3,6 & 3,4 & 3,4 \\
\hline Resistance to change & 2,3 & 2,7 & 3,4 \\
\hline Economic risk & 4,5 & 2,3 & 2,4 \\
\hline Lack of market information & 4,3 & 2,2 & 2,8 \\
\hline Lack of information on technology & 4,0 & 3,2 & 2,3 \\
\hline Difficulty of finding a partner & 4,5 & 2,4 & 2,5 \\
\hline Lack of access to knowledge network & 4,5 & 2,0 & 2,4 \\
\hline No relationship with the university & 4,0 & 2,4 & 2,5 \\
\hline Lack of a policy to protect intellectual prop- & 3,8 & 2,0 & 2,8 \\
\hline Lack of results of R\&D. & 2,7 & 2,6 & 2,6 \\
\hline Percentage among the companies participat- & $\mathbf{5 , 2 6 \%}$ & $\mathbf{5 5 , 2 7 \%}$ & $\mathbf{3 9 , 4 7 \%}$ \\
\hline ing in the survey & & & \\
\hline
\end{tabular}


Achelhi, H., Lagziri, N., Bennouna, M., Truchot, P. (2016). Barriers to innovation in Morocco: The Case of Tangier \& Tetouan Region. International Journal of Social Sciences and Education Research, 2 (2), $592-$ 612.

The size of the company seems to play an important role in the configuration of the obstacles faced by all businesses. The most immediate conclusion that can be drawn from table 2 is that small firms are more likely to evaluate all the obstacles of a medium or high importance. Taking a further look, the largest differences between small and large companies are financial and human barriers. The lack of qualified personnel is a factor that is clearly seen most often in small businesses. Also the absence of relations with the university, difficulty in finding partners and access to knowledge networks are all barriers that prevent VSEs the region to innovate. These factors are also in agreement with the conclusions of the theoretical analysis which highlights the challenges faced by small businesses because of their size. This difference is less pronounced for other barriers such as government policy, culture or lack of R\&D results.

\subsection{The severity of barriers to innovation in the Tangier-Tetouan region by company type}

In a region like Tangier-Tetouan where the percentage of foreign firms is high due to the presence of several free zones, the proximity to an international port, and the geographical position of the region. We raised the question about barriers faced by foreign companies, are they of the same nature as those encountered by domestic firms? In what follows, we will try to answer this question by taking the difference in terms of innovation barriers between domestic and foreign firms. Table 3 shows the percentage of each severity by type of business: domestic and foreign.

Table 3 . The severity of barriers to innovation by company type

\begin{tabular}{|c|c|c|}
\hline Severity of barrier & National firms & Foreign firms \\
\hline $\mathbf{5}$ & $39 \%$ & $8 \%$ \\
\hline $\mathbf{4}$ & $28 \%$ & $22 \%$ \\
\hline $\mathbf{3}$ & $7 \%$ & $23 \%$ \\
\hline $\mathbf{2}$ & $16 \%$ & $17 \%$ \\
\hline $\mathbf{1}$ & $10 \%$ & $30 \%$ \\
\hline
\end{tabular}

From this table, we notice a difference "sometimes significant" on the severity of the barrier for the two types of firms: national and foreign. Indeed, 39\% of national companies, it exists between the barriers suggested in the survey, the barriers that make innovation possible. By cons, only $8 \%$ of foreign companies confirm this result. In the same instance, $23 \%$ of foreign companies consider that among the list of proposed barriers blocking medium innovation, while only $7 \%$ of the national companies confirm this statement.

Responding rate among major foreign companies consider that some barriers are not influenced by innovation. This result is interesting insofar as it confirms the theoretical results and shows that foreign and domestic firms do not share the same vision for the barriers to innovation. Consequently, we distinguish in our study between the barriers of innovation among domestic and foreign firms. Of the 76 companies surveyed in the region, there are 30 domestic companies and 46 foreign companies.

\section{i. $\quad$ National firms}

For the 30 national companies operating in the area, table 4 presents the average severity of each obstacle. 
Achelhi, H., Lagziri, N., Bennouna, M., Truchot, P. (2016). Barriers to innovation in Morocco: The Case of Tangier \& Tetouan Region. International Journal of Social Sciences and Education Research, 2 (2), $592-$ 612.

Table 4. La average severity of obstacles in the case of the national firms

\begin{tabular}{|l|c|c|}
\cline { 2 - 3 } \multicolumn{1}{c|}{} & The average & Deviation \\
\hline Strategy management & 4,4 & 1,034 \\
\hline Government policy & 2,4 & 1,432 \\
\hline The high cost of innovation & 3,4 & 0,845 \\
\hline Unqualified personnel & 4,2 & 1,064 \\
\hline Culture & 3,6 & 1,051 \\
\hline Resistance to change & 3,6 & 1,067 \\
\hline Economic risk & 2 & 1,501 \\
\hline Lack of market information & 3,6 & 1,067 \\
\hline Lack of information on technology & 3,4 & 0,98 \\
\hline Difficulty of finding a partner & 1,4 & 1,67 \\
\hline Lack of access to knowledge network & 2,8 & 1,064 \\
\hline No relationship with the university & 3,4 & 1,116 \\
\hline Lack of a policy to protect intellectual property rights & 3 & 1,172 \\
\hline Lack of results of R\&D. & 1,6 & 1,165 \\
\hline
\end{tabular}

The most prominent result for barriers of innovation in national firms located in the region of Tangier-Tetouan is the number of obstacles which the average $\geq 3$. More than $71 \%$ of the barriers are considered as the major obstacles for innovation in the region. Management strategy and government policy barriers are the barriers designed to make innovation impossible. These two obstacles are considered as the most stringent by domestic firms.

\section{ii. Foreign firms}

The same work was done for the 46 foreign companies. The result is presented in the following table:

Table 5.The average severity of obstacles in the case of foreign firms

\begin{tabular}{|l|c|c|}
\cline { 2 - 3 } \multicolumn{1}{c|}{} & The average & Deviation \\
\hline Strategy management & 3,89 & 0,89 \\
\hline Government policy & 2,44 & 1,14 \\
\hline The high cost of innovation & 2,78 & 1,2 \\
\hline Unqualified personnel & 2,33 & 1,23 \\
\hline Culture & 3 & 1,13 \\
\hline Resistance to change & 3 & 1,3 \\
\hline Economic risk & 2,67 & 1,43 \\
\hline Lack of market information & 2,44 & 1,026 \\
\hline Lack of information on technology & 1,89 & 1,02 \\
\hline Difficulty of finding a partner & 2,89 & 1 \\
\hline Lack of access to knowledge network & 2,33 & 1,1 \\
\hline No relationship with the university & 2,33 & 1,1 \\
\hline Lack of a policy to protect intellectual property rights & 1,89 & 1,16 \\
\hline Lack of results of R\&D. & 2 & 1 \\
\hline
\end{tabular}

For this category of firms, the number of serious obstacles is much more limited than domestic firms. For foreign companies, the biggest obstacle that makes innovation difficult or impossible is the strategy of direction. The other two barriers reported as important in the innovation process for these companies are the culture and the lack of qualified personnel. 
Achelhi, H., Lagziri, N., Bennouna, M., Truchot, P. (2016). Barriers to innovation in Morocco: The Case of Tangier \& Tetouan Region. International Journal of Social Sciences and Education Research, 2 (2), 592612.

\subsection{The relationship between barriers to innovation in the Tangier-Tetouan region}

To find the relationship between the barriers of innovation in the Tangier-Tetouan region, we used the Delphi method. The research must therefore be made on the basis of expert opinions on the relationship between the barriers of innovation in the region. In the course of investigation Delphi, we have respected the seven steps of the method. Thus, having developed the questionnaire, we selected a number of experts that meet the criteria previously appointed. Then, we administered the questionnaire for the first time. After an initial analysis of the responses, we again administered the questionnaire by asking experts to review their answers (opinions) and to respond to specific questions based on the feedback (feedback) that came from other participants in this study. We repeated this process until the respondents reached a satisfactory degree of consensus, which required three rounds.

In the first round, we presented the experts 14 barriers of innovation validated in the previous steps. We asked each expert to determine the relationship of dependency and influence between the barriers. In the second round, a report of the first round Delphi was provided to the participating experts. Thus, according to this report, the experts were asked to comment on specific questions on their consensus and their disagreement opinions.

Finally, in the third round a report was produced of the second round and we proposed the experts make their comments on the points of consensus and disagreements and to validate the matrix of relationships between the barriers of innovation in the Tangier-Tetouan region. The specific objective of the third round of the Delphi survey was to highlight the meaning of the relationship between the barriers of innovation in the Tangier-Tetouan region. The questionnaire for the third and final round was emailed to thirteen experts who responded to the second round of our Delphi survey. In general, the third round of the Delphi survey was designed to confirm the results obtained and the consensus around certain relationships between the barriers and the relationship direction. After consulting all experts, the SSIM following matrix is validated:

Table 6. Structural Self Interaction Matrix (SSIM)

\begin{tabular}{|c|c|c|c|c|c|c|c|c|c|c|c|c|c|c|}
\hline & \multirow[b]{2}{*}{ Barriers } & \multicolumn{13}{|c|}{ Numbers barriers } \\
\hline & & 14 & 13 & 12 & 11 & 10 & 9 & 8 & 7 & 6 & 5 & 4 & 3 & 2 \\
\hline 1 & Strategy management & $\mathrm{V}$ & $\mathrm{A}$ & $\mathrm{A}$ & $\mathrm{X}$ & $\mathrm{V}$ & $\mathrm{A}$ & $\mathrm{X}$ & $\mathrm{X}$ & $\bar{X}$ & $\mathrm{~V}$ & $\mathrm{X}$ & $\mathrm{X}$ & $\mathrm{X}$ \\
\hline 2 & Economic risk & $\mathrm{V}$ & $\mathrm{X}$ & $\mathrm{X}$ & $\mathrm{X}$ & $\mathrm{A}$ & $\mathrm{A}$ & $\mathrm{A}$ & $\mathrm{V}$ & $\mathrm{O}$ & $\mathrm{X}$ & $\mathrm{A}$ & $\mathrm{A}$ & $\mathrm{X}$ \\
\hline 3 & The high cost of innovation & $\mathrm{X}$ & $\mathrm{X}$ & $\mathrm{O}$ & $\mathrm{V}$ & $\mathrm{X}$ & $\mathrm{X}$ & $\mathrm{V}$ & $\mathrm{V}$ & $\mathrm{O}$ & $\mathrm{V}$ & $\mathrm{X}$ & $\mathrm{X}$ & \\
\hline 4 & Government policy & $\mathrm{V}$ & $\mathrm{V}$ & $\mathrm{V}$ & $\mathrm{A}$ & $\mathrm{V}$ & $\mathrm{O}$ & $\mathrm{V}$ & $\mathrm{O}$ & $\mathrm{V}$ & $\mathrm{V}$ & $\mathrm{X}$ & & \\
\hline 5 & Unqualified personnel & $\mathrm{O}$ & $\mathrm{O}$ & $\mathrm{O}$ & $\mathrm{O}$ & $\mathrm{X}$ & $\mathrm{A}$ & $\mathrm{V}$ & $\mathrm{V}$ & $\mathrm{X}$ & $\mathrm{X}$ & & & \\
\hline 6 & Culture & $\mathrm{O}$ & $\mathrm{O}$ & $\mathrm{O}$ & $\mathrm{O}$ & $\mathrm{V}$ & $\mathrm{O}$ & $\mathrm{O}$ & $\mathrm{V}$ & $\mathrm{X}$ & & & & \\
\hline 7 & Resistance to change & $\mathrm{O}$ & $\mathrm{O}$ & $\mathrm{O}$ & $\mathrm{O}$ & $\mathrm{A}$ & $\mathrm{O}$ & $\mathrm{O}$ & $\mathrm{X}$ & & & & & \\
\hline 8 & Difficulty of finding a partner & $\mathrm{O}$ & $\mathrm{X}$ & $\mathrm{V}$ & A & $\mathrm{V}$ & $\mathrm{V}$ & $\mathrm{X}$ & & & & & & \\
\hline 9 & Lack of access to knowledge network & $\mathrm{O}$ & $\mathrm{V}$ & $\mathrm{V}$ & $\mathrm{X}$ & A & $\mathrm{X}$ & & & & & & & \\
\hline 10 & No relationship with the university & $\mathrm{O}$ & $\mathrm{O}$ & A & A & $\mathrm{X}$ & & & & & & & & \\
\hline 11 & Lack of results of $\mathrm{R} \& \mathrm{D}$. & $\mathrm{V}$ & $\mathrm{A}$ & $\mathrm{A}$ & $\mathrm{X}$ & & & & & & & & & \\
\hline 12 & Lack of information on technology & $\mathrm{V}$ & $\mathrm{X}$ & $\mathrm{X}$ & & & & & & & & & & \\
\hline 13 & Lack of market information & A & $\mathrm{X}$ & & & & & & & & & & & \\
\hline 14 & $\begin{array}{l}\text { Lack of a policy to protect intellectual } \\
\text { property }\end{array}$ & $\mathrm{X}$ & & & & & & & & & & & & \\
\hline
\end{tabular}


Achelhi, H., Lagziri, N., Bennouna, M., Truchot, P. (2016). Barriers to innovation in Morocco: The Case of Tangier \& Tetouan Region. International Journal of Social Sciences and Education Research, 2 (2), 592612.

Based on contextual relationships, SSIM has been developed (Table 6). Obstacle 1 leads to barriers 5, 10 and 14. In this sense the symbol "V" was given in the cells (1.5), (1.10) and (1.14). The barriers 9,12 and 13 will be affected by the barrier 1 . Consequently, the symbol 'A' was given in cell (1.9), (1.12) and (1.13).

The barriers $2,3,4,6,7,8$, and 11 lead with barrier 1 to reach other barriers, thus a symbol "X" was given in cells $(1,2) ;(1,3),(1,4),(1,6),(1,7),(1,8)$ and $(1,11)$.

Barriers 2 and 6 are not connected, so a symbol "O" was given in the cell $(2,6)$. And so on for the rest of the table, the same work was done with all barriers to achieve self interaction matrix SSIM between the barriers of innovation in the Tangier-Tetouan region.

According to the results of the Delphi survey, we were able to determine any relationships between the barriers of innovation in the Tangier-Tetouan region. Moreover, it appears from our survey results and comments from experts that the choice of using the Delphi method in this stage of our research was appropriate to reach a consensus on the relationship between barriers to innovation in region.

\subsubsection{Accessibility matrix}

To better exploit the results of the Delphi survey. We found it interesting to use the matrix to determine the accessibility conductive powers and powers of dependencies barriers to innovation in the Tangier-Tetouan region. Initial reachability matrix for barriers which is obtained by substituting $\mathrm{X}, \mathrm{A}, \mathrm{V}, \mathrm{O}$ by 1 and 0 is shown in Table 7 .

Table 7. The initial matrix accessibility

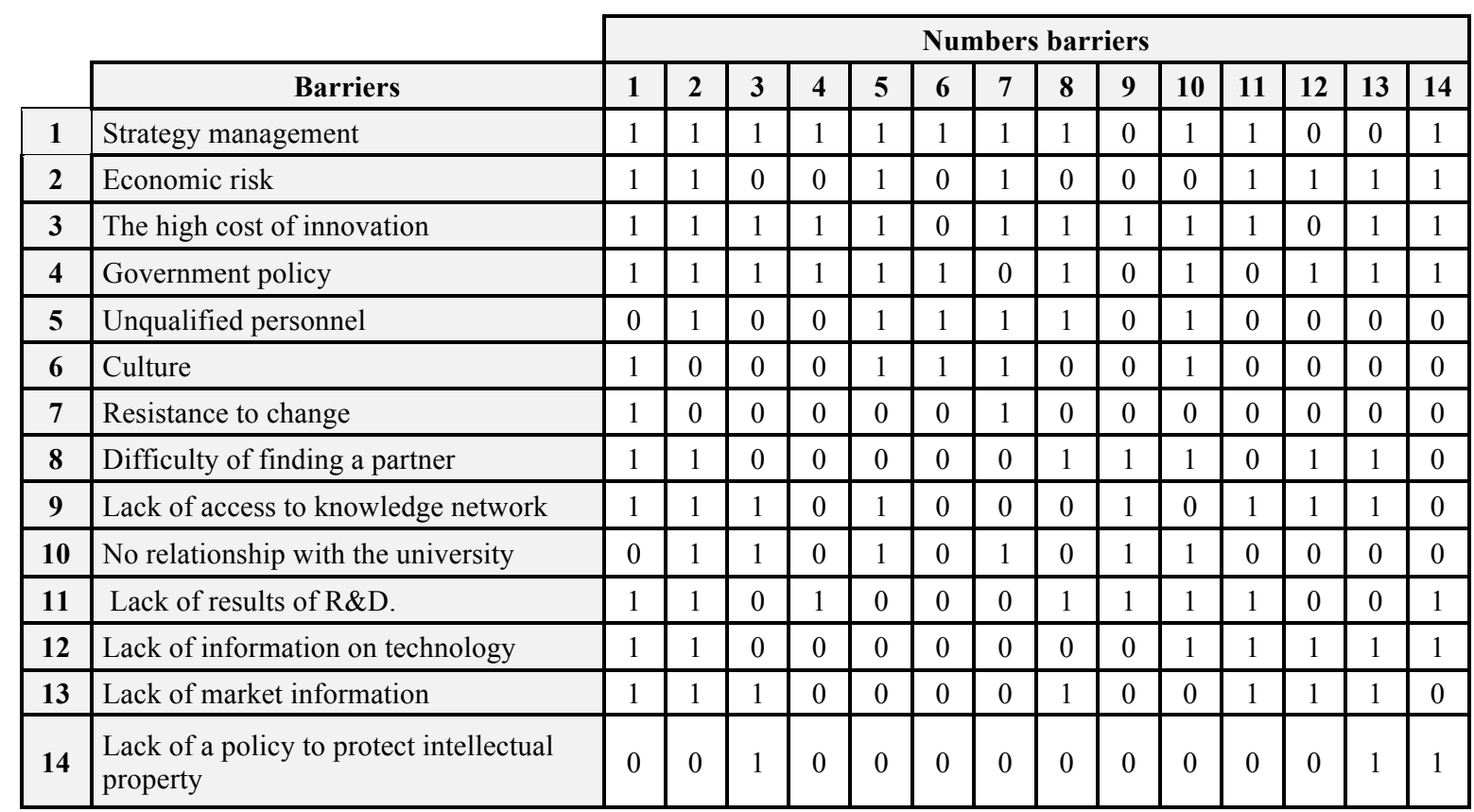

After incorporating the transivity, the final reachability matrix is shown in table 8 , in which the driving power and dependence power of each barrier are also shown. Driving power of each barrier is the total number of barriers (including itself), which it may help achieve. On the other hand, dependence is the total number of barriers (including itself), which may help inachieving 
Achelhi, H., Lagziri, N., Bennouna, M., Truchot, P. (2016). Barriers to innovation in Morocco: The Case of Tangier \& Tetouan Region. International Journal of Social Sciences and Education Research, 2 (2), 592612.

it. These driving power and dependencies will be later used in the classification of barriers into the four groups of autonomous, dependent, linkage and independent (driver) barriers.

Table 8 . Final reachability matrix

\begin{tabular}{|c|c|c|c|c|c|c|c|c|c|c|c|c|c|c|c|c|}
\hline & & \multicolumn{14}{|c|}{ Numbers barriers } & \multirow[b]{2}{*}{\begin{tabular}{|c} 
Driv- \\
ing \\
Powe \\
$r$
\end{tabular}} \\
\hline & Barriers & 1 & 2 & 3 & 4 & 5 & 6 & 7 & 8 & 9 & 10 & $\begin{array}{l}1 \\
1\end{array}$ & 12 & $\begin{array}{l}1 \\
3\end{array}$ & 14 & \\
\hline 1 & Strategy management & 1 & 1 & 1 & 1 & 1 & 1 & 1 & 1 & 0 & 1 & 1 & 0 & 0 & 1 & 11 \\
\hline 2 & Economic risk & 1 & 1 & 0 & 0 & 1 & 0 & 1 & 0 & 0 & 0 & 1 & 1 & 1 & 1 & 8 \\
\hline 3 & The high cost of innovation & 1 & 1 & 1 & 1 & 1 & 0 & 1 & 1 & 1 & 1 & 1 & 0 & 1 & 1 & 12 \\
\hline 4 & Government policy & 1 & 1 & 1 & 1 & 1 & 1 & 0 & 1 & 0 & 1 & 0 & 1 & 1 & 1 & 11 \\
\hline 5 & Unqualified personnel & 0 & 1 & 0 & 0 & 1 & 1 & 1 & 1 & 0 & 1 & 0 & 0 & 0 & 0 & 6 \\
\hline 6 & Culture & 1 & 0 & 0 & 0 & 1 & 1 & 1 & 0 & 0 & 1 & 0 & 0 & 0 & 0 & 5 \\
\hline 7 & Resistance to change & 1 & 0 & 0 & 0 & 0 & 0 & 1 & 0 & 0 & 0 & 0 & 0 & 0 & 0 & 2 \\
\hline 8 & Difficulty of finding a partner & 1 & 1 & 0 & 0 & 0 & 0 & 0 & 1 & 1 & 1 & 0 & 1 & 1 & 0 & 7 \\
\hline 9 & Lack of access to knowledge net- & 1 & 1 & 1 & 0 & 1 & 0 & 0 & 0 & 1 & 0 & 1 & 1 & 1 & 0 & 8 \\
\hline 10 & No relationship with the univer- & 0 & 1 & 1 & 0 & 1 & 0 & 1 & 0 & 1 & 1 & 0 & 0 & 0 & 0 & 6 \\
\hline 11 & Lack of results of R\&D. & 1 & 1 & 0 & 1 & 0 & 0 & 0 & 1 & 1 & 1 & 1 & 0 & 0 & 1 & 8 \\
\hline 12 & Lack of information on technol- & 1 & 1 & 0 & 0 & 0 & 0 & 0 & 0 & 0 & 1 & 1 & 1 & 1 & 1 & 7 \\
\hline 13 & Lack of market information & 1 & 1 & 1 & 0 & 0 & 0 & 0 & 1 & 0 & 0 & 1 & 1 & 1 & 0 & 7 \\
\hline \multirow[t]{2}{*}{14} & $\begin{array}{l}\text { Lack of a policy to protect intel- } \\
\text { lectual property }\end{array}$ & 0 & 0 & 1 & 0 & 0 & 0 & 0 & 0 & 0 & 0 & 0 & 0 & 1 & 1 & 3 \\
\hline & Dependence Power & 11 & 1 & 7 & 4 & 8 & 4 & 7 & 7 & 5 & 9 & 7 & 6 & 8 & 7 & \\
\hline
\end{tabular}

\subsubsection{Analysis Mic Mac}

«Strategy management», «the high cost of innovation» and «economic risk» are considered bind variables that have strong driving power and a strong dependence. A little change in "strategy management" and the problem of "high cost of innovation" and that the problem of "economic risk" affects the system in a huge way.

"The lack of relationship with the university," "Unqualified personnel", "resistance to change", "the lack of protection of industrial property" are weak drivers but strongly depends on other variables. They are considered as facilitators barriers. "Government policy" and "lack of access to knowledge networks" are variables that have powers of driving. Thus, it should be treated first if you're looking surpassing barriers to innovation. The government should develop strategies to improve the deployment of independent variables so that the innovation performance is improved. "The culture" is a barrier with a low dependency and it is weak drivers. It is considered an independent barrier. 
Achelhi, H., Lagziri, N., Bennouna, M., Truchot, P. (2016). Barriers to innovation in Morocco: The Case of Tangier \& Tetouan Region. International Journal of Social Sciences and Education Research, 2 (2), $592-$ 612.

Figure 1. Driver Power and dependence diagram

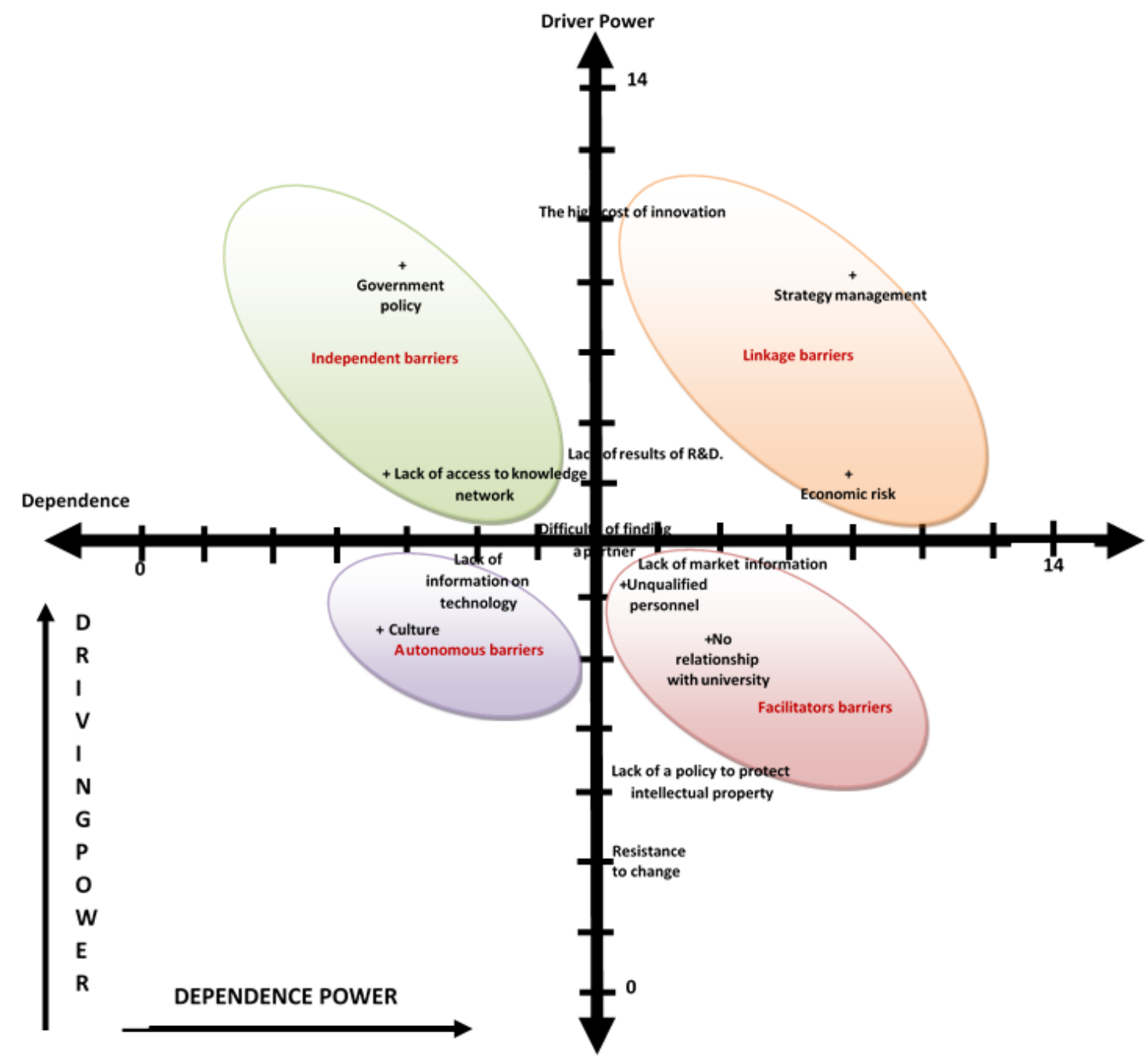

\subsection{Barriers to innovation models}

\subsubsection{Barriers to innovation models of the domestic firms}

In the case of domestic firms located in the region Tanger-Tétouan, government policy is the biggest obstacle. This barrier is positioned at the highest level in the model hierarchy; "Government policy » is a barrier independently associated with several other barriers (strategy, unqualified personnel, culture, innovation costs, the difficulty in finding partners, lack of information on technology, lack network access knowledge ...). This barrier should be treated first in order to improve the innovation system of domestic firms. 
Achelhi, H., Lagziri, N., Bennouna, M., Truchot, P. (2016). Barriers to innovation in Morocco: The Case of Tangier \& Tetouan Region. International Journal of Social Sciences and Education Research, 2 (2), 592612.

Figure 2. The innovation barriers model of domestic firms in the Tangier-Tetouan region

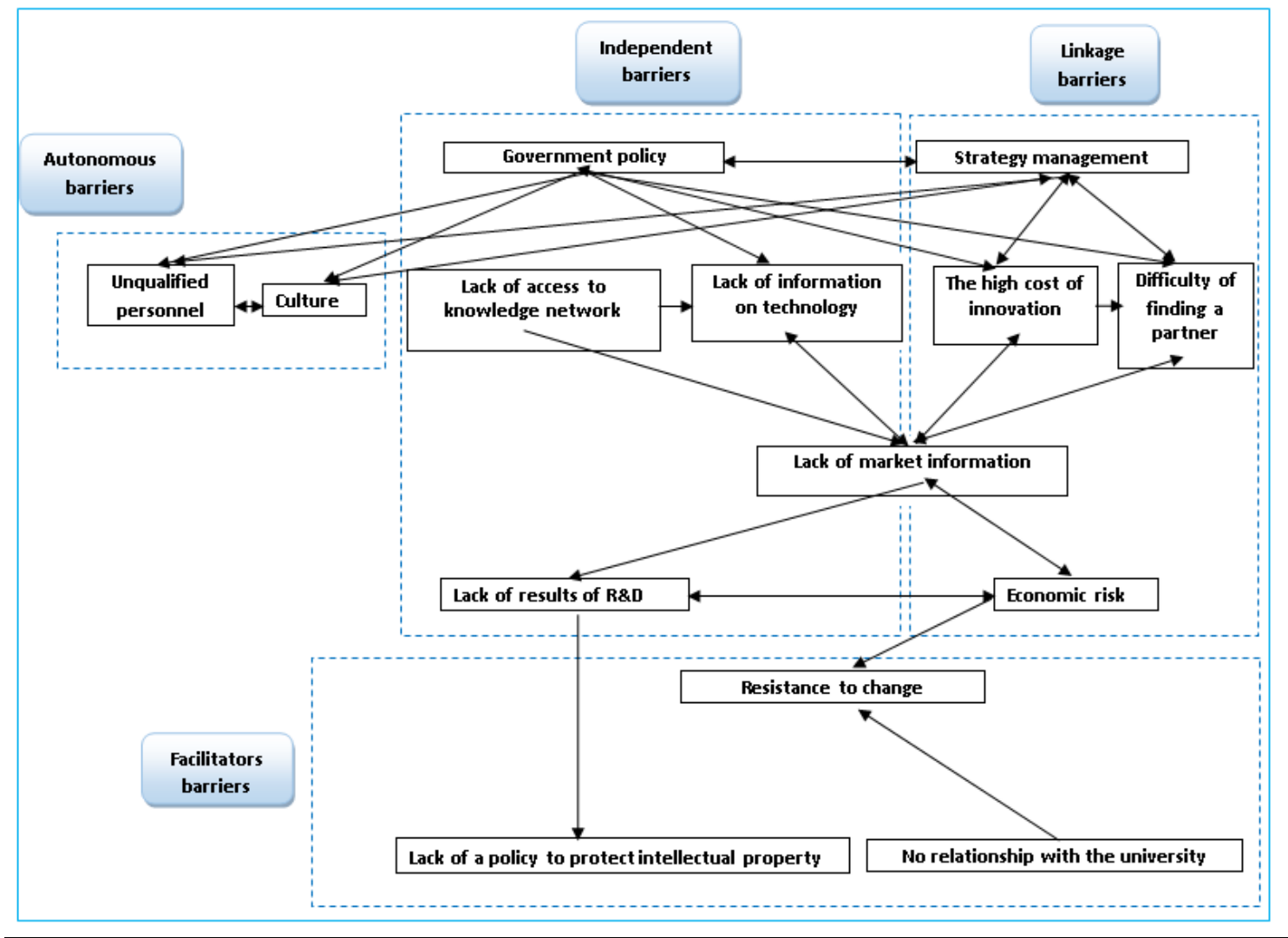

The barrier "resistance to change" is positioned at the lowest level of the model. This due to its high power dependence and the low driving power and also has a low severity compared to other barriers. Barriers which are the second and third level of the model play a key role in sharing knowledge, research and also in collaboration. These obstacles require greater attention from top management and decision managers. Driving power and dependency diagram provide some valuable insights into the relative importance and interdependence of these obstacles.

The barriers autonomous as culture and unqualified personnel are the strong factors despite their low power dependence. They have a high degree of severity, so they are classified the second level of the model. These barriers must attack independently and in a priority as the strategy and policy government. The domestic firms also share the problem of the cost of innovation: Financial problems and lack of a state guarantee for innovative projects ... as well as the difficulty in finding partners in this topic pose a real risk to those companies that are in most cases SMEs. Adding the lack of access to the network of knowledge and lack of information on technology and markets, domestic firms suffer from a lack of sufficient information that will allow them to better track the level strategies to innovate products, which leads to the increase of the economic risk.

\subsubsection{Barriers to innovation models of the foreign firms}

Figure 3 shows the model of innovation barriers in foreign companies operating in the TangierTetouan region. Analyzing this model, we note that the barrier "Strategy management" is the biggest barrier to innovation in the case of foreign companies operating in Morocco. If the foreign company does not have an innovation strategy in Morocco, all of the innovation system is 
Achelhi, H., Lagziri, N., Bennouna, M., Truchot, P. (2016). Barriers to innovation in Morocco: The Case of Tangier \& Tetouan Region. International Journal of Social Sciences and Education Research, 2 (2), $592-$ 612.

blocked. This obstacle classified at the highest level of barriers to innovation model, it is an obstacle that link pulse is important, but also a strong dependence. This obstacle is unstable because any action on this obstacle has an immediate effect on the others barriers and also back on themselves.

Figure 3. The innovation barriers model of foreign firms operating in the Tangier-Tetouan region

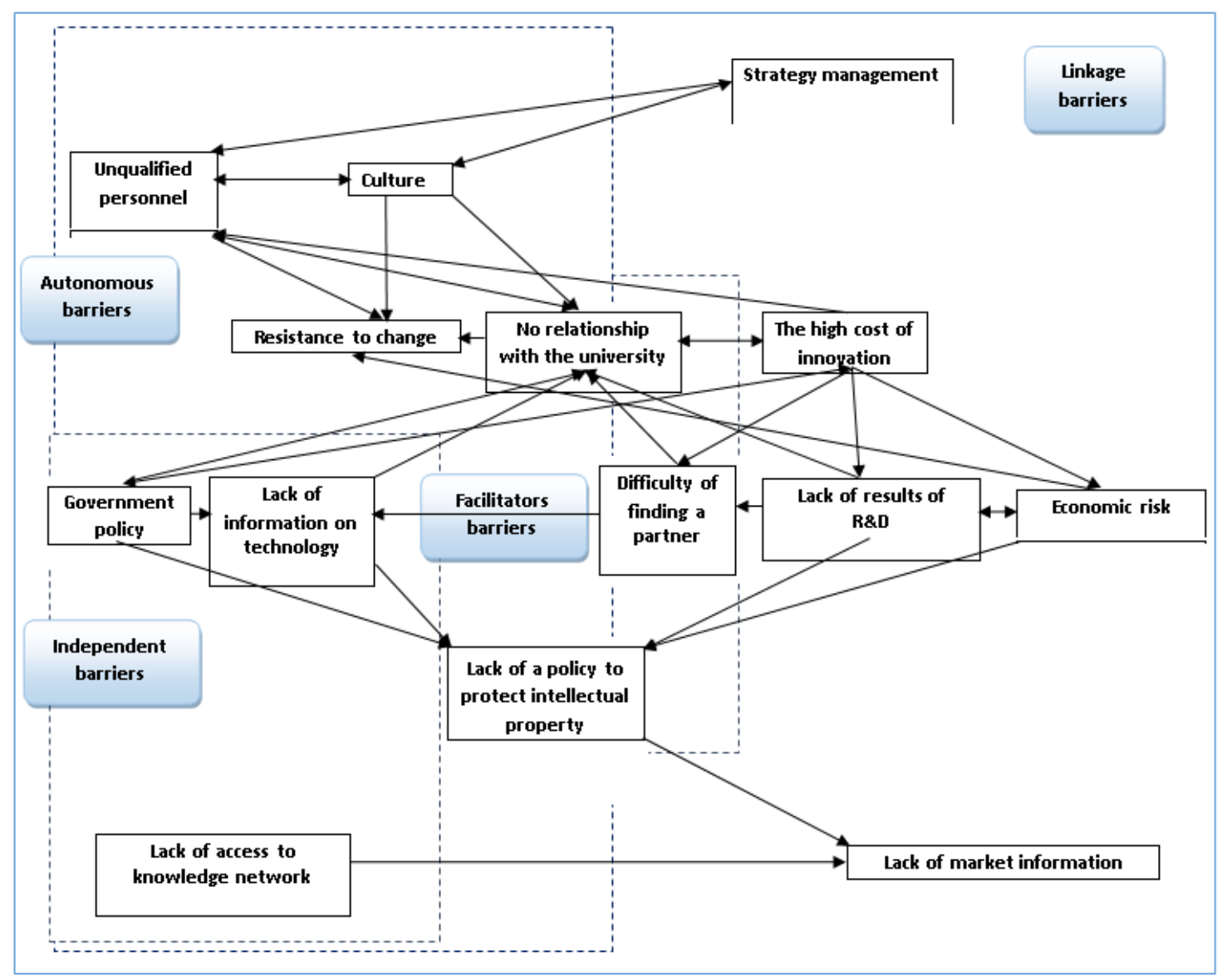

The two barriers "culture" and "unqualified personnel" is positioned at the second level of the model. Culture influences and is influenced by "strategy management". Consequently, draw a successful innovation strategy in the company, is also act on the development of a culture of innovation in the business. The reverse is also true, have a culture of innovation within the company, enabling managers to engage more easily in innovative projects. The absence of a culture of innovation plays a role in the presence of a resistance to change and lack of relationship with the university which implies the presence of unqualified personnel. Despite whether a barrier autonomous, "culture" is indirectly involved in the interactions of causality several with other barriers.

Unqualified personnel, influences and is influenced by: culture, resistance to change and lack of relationship between the company and the university. This barrier is very important because human resources are the basis of all innovation. The presence of qualified personnel in innovation will help the company move more quickly in an innovative project. At the third level of the model, we find the policy government. This barrier has been ranked at the top level in the case of domestic 
Achelhi, H., Lagziri, N., Bennouna, M., Truchot, P. (2016). Barriers to innovation in Morocco: The Case of Tangier \& Tetouan Region. International Journal of Social Sciences and Education Research, 2 (2), 592612

firms and he has also the importance for foreign companies. In the case of these companies, the policy government must address the problem of "the lack of relations with the university", "the lack of information on technology", "the cost of innovation" and "the problem of lack of protection industrial property".

They expect the government to create a favourable environment for innovation through training of qualified personnel, the implementation available to laboratories, research centres and experts to help innovation and to help strengthen partnership relations with the university in order to reduce the cost of innovation.

In this third level of the model, we also find the "economic risk" that influences the resistance to change and lack of protection of industrial property. This barrier also influenced by the high cost of innovation and the lack of results of R\&D. Taking a risk to innovate is a culture and strategy. An important note for "lack of access to knowledge network" in the case of domestic companies, this barrier was ranked in the second level, in the case of foreign companies; it is ranked in the last level with a level with a little effect on the barriers to innovation. The status of foreign companies will allow these businesses to access more easily than domestic firms to knowledge networks, so the importance of this barrier in this case is low.

\section{Industrial Application: Example of collaboration between a university and a regional firm}

In this section, we present one of the solutions that can help to overcome the barriers of innovation resulting from our various investigations. In this sense, we choose a local company operative in the automotive industry (This is one of the largest companies in the region, it employs $10 \%$ of the total employees in the Tangier free zone: about 5000 employees), and we suggere to this company to working on an innovative project with the university using the innovation platform CP2I (Conception of Integrated Products and Innovation). CP2I is composed of engineers and researchers in different fields: technical, human, organizational, marketing ... working with tools and software to support innovation and development.

In Morocco, the University Abdelmalek Essaadi took the lead in creating a platform in 2011 called CP2I. This platform is in synergy with other innovation platforms, including Cré@crtion of ENSGSI Nancy (National School of Industrial Systems Engineering) France, innovation platforms Milan (Italy), Barcelona (Spain), Tunis and Sousse (Tunisia) in the context of a Tempus project which began in 2009.

\subsection{Description of the collaborative project}

The project is to find an innovative solution to an organizational problem which society suffers since ten years. The project involves various actors in the business: production, logistics, purchasing, engineering, human resources management... and academic actors: an engineer, teachers' researcher, a doctoral students and students. Our empirical study was conducted in two levels:

1- A longitudinal study of the company that brings together the project team. This study lasted nine months (March 2012-November 2012).

2- A series of interviews (after the nine months of observation and participation with the project team). 
Achelhi, H., Lagziri, N., Bennouna, M., Truchot, P. (2016). Barriers to innovation in Morocco: The Case of Tangier \& Tetouan Region. International Journal of Social Sciences and Education Research, 2 (2), 592612.

Outline of questions were sent, and all interviews were recorded. During the interviews, we collected as much information on the various barriers encountered in the project. After nine months of work, the project was a great success.

Types of innovations proposed in this project are organizational and technological levels. But the type of innovation applied and chosen by the management of the company is "organizational". This because the company has to follow specifications imposed by the parent company, so she cannot innovate in product. Throughout the project, several obstacles including those related to human resources appear to be the most important in this project. Followed by those related to the attributes of the innovation itself, including the negative image that may have organizational innovation.

Internal barriers (structural, related to financial and human resources) are those most often mentioned spontaneously in response to the open question "What were the biggest challenges of this project?" External barriers such as difficulty in finding partners, market information and technology or the results of R\&D are those whose actors interviewed made the state less.

Table 9, provides a comparison of the ranking of barriers to innovation identified and indicates their importance in terms of perceived effects on the innovation process before and after the collaboration between the platform CP2I and the company.

Table 9. Comparison degree of importance of barriers before and after the collaborative project between the platform CP2I and the firm

\begin{tabular}{|l|c|c|}
\hline & $\begin{array}{c}\text { Before collaboration } \\
\text { with CP2I }\end{array}$ & $\begin{array}{c}\text { After collaboration } \\
\text { with CP2I }\end{array}$ \\
\hline Strategy management & 4 & 3 \\
\hline Economic risk & 4 & 3 \\
\hline The high cost of innovation & 4 & 2 \\
\hline Government policy & 3 & 2 \\
\hline Unqualified personnel & 4 & 1 \\
\hline Culture & 4 & 0 \\
\hline Resistance to change & 4 & 0 \\
\hline Difficulty of finding a partner & 4 & 0 \\
\hline Lack of access to knowledge network & 4 & 0 \\
\hline No relationship with the university & 3 & 1 \\
\hline Lack of results of R\&D. & 2 & 0 \\
\hline Lack of information on technology & 2 & 1 \\
\hline Lack of market information & 4 & \\
\hline $\begin{array}{l}\text { Lack of a policy to protect intellectual prop- } \\
\text { erty rights }\end{array}$ & 4 & \\
\hline
\end{tabular}


Achelhi, H., Lagziri, N., Bennouna, M., Truchot, P. (2016). Barriers to innovation in Morocco: The Case of Tangier \& Tetouan Region. International Journal of Social Sciences and Education Research, 2 (2), $592-$ 612.

We note that the barriers: "Lack of protection of industrial property, lack of market information, lack of information on technology, the lack of results of $\mathrm{R} \& \mathrm{D}$, the lack of relationship with the university, the difficulty of finding partners and the resistance to change", have lowered significantly. This collaboration can also reduce the severity of the barriers: «Culture, government policy, economic risk, the high cost of innovation and unqualified personnel».

Our research reveals that collaboration between academia and industry can promote the development of innovation: Half barriers were removed by this collaboration and the second half was down in terms of severity the barriers. The expertise of the platform CP2I in this type of projects allows better success of this project, and especially she helped in overcoming the negative image of innovation within this firm.

Figure 4. Comparison between the data input and output of the collaboration platform CP2I and the regional firm

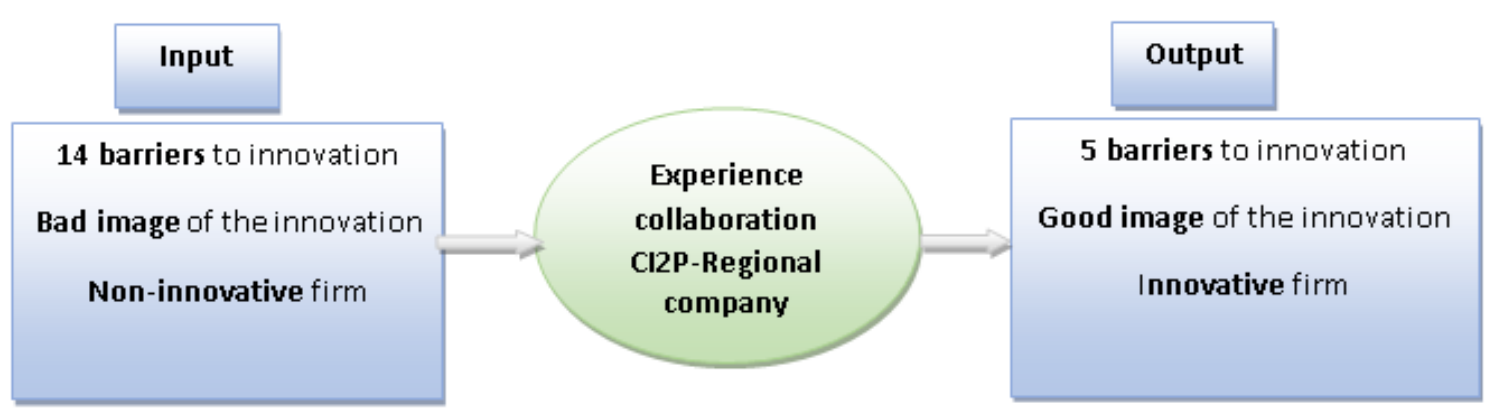

\section{Discussion and conclusions}

One of the major objectives of this study is to identify and rank the innovation barriers in the Tangier-Tetouan region. An identification of barriers can assist in fostering an innovative culture in firms by supporting new ideas or galvanizing proper innovation management. On a national level, it is important to identify and remove barriers in order to foster innovation based on competition and to not allow failure to innovate (Woolthuis, 2005; Chaminade and al. 2009).

This research has shown that there is a big difference in the perception of obstacles to innovation depending on the type of business. In this sense, we have focused our research to determine whether domestic firms face the same obstacles that foreign companies face. While one might expect that the large foreign companies would face several gaps in the literature, the results of our study in the Moroccan context were reversed. Domestic firms were more likely to report at least one more obstacle compared to foreign companies that are in larger companies.

On the other hand, the ranking of obstacles "high" importance was different between domestic and foreign firms. Barriers such as "government policy", "the lack of information on the technology and the market", "the difficulty in finding partners" and "lack of access to knowledge networks", that there are barriers with at least two different levels each between foreign and domestic firms. Conversely, other barriers such as resistance to change and lack of relationship with the university, advances in the hierarchy levels in the case of the foreign companies.

However, it is interesting to note that both companies have agreed on the level of importance and classification of three types of barriers: Culture, strategy and lack of qualified staff. While 
Achelhi, H., Lagziri, N., Bennouna, M., Truchot, P. (2016). Barriers to innovation in Morocco: The Case of Tangier \& Tetouan Region. International Journal of Social Sciences and Education Research, 2 (2), $592-$ 612.

strategic barriers are important in determining the structure of the innovation process, qualified personnel are more important in improving this process.

The fact that companies classify the lack of qualified personnel as one of the most important obstacles to innovation, and the lack of relationship with the university as an obstacle to a low level of importance, we have led us to inquire in the several questions. How companies feel that the relationship with the university is not a significant barrier to innovation knowing that it is the university that has trained their personnel?

In this sense, we investigated in this point and using a real example of collaboration between university and enterprise in the region. This project has shown us that collaboration between universities and business in innovation in the region, will act to overcome several obstacles. The results have been surprising; more than $60 \%$ of barriers have been eliminated or reduced in a way significant thanks to this collaboration. This research has enabled us to identify the main points on which action is needed to develop innovation in the region:

$\checkmark \quad$ The business strategy,

$\checkmark$ The company's relationship with University,

$\checkmark$ Government policy,

$\checkmark \quad$ The culture of innovation.

\section{References}

Acs, ZJ and DB Audretsch (1991). R\&D, Firm Size and Innovative Activity.

Afrooz, N (2012). A Study of Levels and Characteristics of Innovation Activity, Global Journal of Management and Business Research, Volume 12 Issue 8 Version 1.0 May 2012, Type: Double Blind Peer Reviewed International Research Journal, Publisher: Global Journals Inc. (USA), Online ISSN: 22494588 \& Print ISSN: 0975-5853.

Baldwin, J and X Lin (2002). Impediments to advanced technology adoption for Canadian manufacturers. Research Policy, 31, $1-18$.

Canepa, A, and P. Stoneman. (2002), Financial constraints on innovations: A European cross country study, Kiel Institute of World Economics, Working paper no. 02-11.

Chaminade, C, BA Lundvall, KJ Joseph and J Vang. (2009). Innovation Systems and Developing Countries an introduction in Lundvall. Building Domestic Capabilities in a Global Setting. Edward Elgar, UK, an introduction.

Clancy, J. (2001). Barriers to Innovation in Small-scale Industries: Case Study from the Briquetting Industry in India', Science Technology\&Society 6(2), 329-357.

Dalkey, N and O Helmer. (1963). An experimental application of the Delphi method to the use of expert. Management Science, 9(3), 458-467.

Demirbas, D. (2010). How do Entrepreneurs Perceive Barriers to Innovation? Empirical Evidence from Turkish SMEs, Newcastle Business School, Northumbria University, Newcastle upon Tyne, NE1 8ST, UK.

D'Este, P., S Iammarino, M Savona and N Von Tunzelmann. (2008). What hampers innovation? Evidence from the UK CIS4, SWEPS Electronic Working Paper Series, SPRU 168.

Dougherty, D. (1992). Interpretive barriers to successful product innovations in large firms. Organ. Sci.3(2) 179-202.

Dosi, G.. (1988), «The nature of the innovative process», dans G. Dosi, C. Freeman, R. Nelson, et al. (dir.), Technical Change and Economic Theory, Londres, Pinter Publishers Ltd., p.221-238. 
Achelhi, H., Lagziri, N., Bennouna, M., Truchot, P. (2016). Barriers to innovation in Morocco: The Case of Tangier \& Tetouan Region. International Journal of Social Sciences and Education Research, 2 (2), 592612.

Fes. (2004). SME and Innovation. Friedrich-Ebert-Stiftung Paper 10/2004.

Galia, F and D Legros (2004). Complementarities between obstacles to innovation: evidence from France, Research Policy, 33, 1185-1199.

Gobé M. (2001). Emotional branding: the new paradigm for connecting brands to people Business /design. New York.

González, X, J Jaumandreu and C Pazó (2005). Barriers to innovation and subsidy effectiveness', RAND Journal of Economics 36(4), 930-950.

Hadjimanolis, A. (1999). Barriers to innovation for SMEs in a small less developed country (Cyprus), Technovation, 19, 561-570.

Hadjimanolis, A. (2003). The Barriers approach to innovation», The International Handbook on Innovation, Oxford, Elsevier Science Ltée, p. 559-573.

Henderson, R. (1993). Under investment and incompetence as responses to radical innovation: evidence from the photolithographic alignment equipment industry. Rand Journal of Economics 24, 248-270.

Iammarino, S and P McCann (2006). The Structure and Evolution of Industrial Clusters: Transactions, Technology and Knowledge Spillovers. Research Policy, n 35, pp. 1018-1036.

Kamalian, A, M Rashki and ML Arbabi (2011). Barriers to Innovation among Iranian SMEs. Asian Journal of Business Management 3(2): 79-90, 2011. ISSN: 2041-8752.

Madiès, T and JC Prager (2008). Innovation et compétitivité des regions. Un rapport réalisé en PAO au Conseil d'Analyse Économique Français par Christine Carl.

Madrid-Guijarro, A, G Domingo and H Van Auken (2009). Barriers to Innovation among spanish manufacturing SMEs. J. Small Bus. Manage. Milwaukee, 47(4): 465, 24.

Mandal, A and SG Deskumukh (1994). Vendor Selection Using Interpretive Structural Modelling (ISM). International Journal of Operations and Production Management, 14(6) 52-59.

March-Chordà, I, A Gunasekaran and B Lloria-Aramburo (2002). Product development process in Spanish SMEs: an empirical research. Technovation 22(5), 301-312.

Mohnen, P and L Roller (2005). Complementarities in innovation policy. European Economic Review, 49: 6, 1431-1450.

Mohnen, P and J Rosa (2002). Barriers to innovation in service industries in Canada. In: Feldman, M., Massard, N. (Eds.), Institutions and Systems in the Geography of Innovation, Kluwer Academic Publishers, Boston, 231-250.

Mohnen, P, F Palm, S Van Der Loeff and A Tiwari (2008). Financial constraints and other obstacles: are they a threat to innovation activity? De Economist 156 (2), 201-214.

Nelson, and Winter (1982). An Evolutionary Theory of Economic Change. Belknap Press of Harvard University Press, Cambridge, MA.

Ohmae, K (1995). The End of the Nation State: The Rise of Regional Economies, Harper Collins, Londres.

Piatier, A (1984). Barriers to innovation. Frances Pinter, London.

Ould Aoudia J (2006). «Croissance et réformes dans les pays arabes méditerranéens», Notes et Documents No. 28, Agence Française de Développement, Paris.

Preissl (1998). Barriers to innovation in services. SI4S Topical Paper STEP Group.

Rahmouni, M (2011). Perception of obstacles to innovation activities in Tunisian firms. MPRA Paper No. 18306, posted 19. January 2011.

Saatçioglu, Ö and Ö Özmen (2010). Analyzing the Barriers Encountered in Innovation Process Through Interpretive Structural Modelling: Evidence From Turky. Yonetim Ve Ekonomi.

Segarra-Blasco, A, J Garcia-Quevedo, M Teruel-Carrizosa (2008). Barriers to innovation and public policy in Catalonia, International Entrepreneurship and Management Journal, 4, 431-451. 
Achelhi, H., Lagziri, N., Bennouna, M., Truchot, P. (2016). Barriers to innovation in Morocco: The Case of Tangier \& Tetouan Region. International Journal of Social Sciences and Education Research, 2 (2), 592612 .

Schumpeter, JA (1950). Capitalism, Socialism and Democracy. 3rd Ed. NewYork: Harper\&Row.

Silva, MJ, J Leitao and M Raposo (2008). Barriers to Innovation Faced by Manufacturing Firms in Portugal: How to Overcome it for Fostering Business Excellence. International Journal of Business Excellence 1, 92-105.

Tiwari, R and S Buse (2007). Barriers to innovation In SMEs: Can the internationalization of R\&D Mitigate their Effects? Proceedings of the First European Conference on Knowledge for Growth: Role and Dynamics of Corporate R\&D (Concord 2007), Seville, Spain.

Tourigny D., Le C.D. (2004), Impediments to innovation faced by Canadian manufacturing firms, Economics of Innovation and New Technology $13: 3,217-50$.

Von Hippel, E (1988). The sources of innovation, New-York, Oxford University Press, 218 p.

Woolthuis, RK (2005). A system failure framework for innovation policy design. Technovation 25: 609619.

Yinenpaa, H (1998). Measures to Overcome Barriers to Innovation in Sweden. Paper EFMD European Small Business Seminar in Vienna, 1998, online;http://www.res.luth.se/org/Rapporter/AR9826.pdf last accessed 21.5.2006 Acs, Z. J. et D.B.

Zhu, Y, X Wittmann and Mike W. Peng (2011). Institution-based barriers to innovation in SMEs in China. Asia Pac J Manag DOI 10.1007/s10490-011-9263-7. 